medRxiv preprint doi: https://doi.org/10.1101/2021.03.23.21253873; this version posted March 26, 2021. The copyright holder for this preprint (which was not certified by peer review) is the author/funder, who has granted medRxiv a license to display the preprint in perpetuity.

It is made available under a CC-BY-NC-ND 4.0 International license.

\title{
Estimated Deaths, Intensive Care Admissions and Hospitalizations Averted in Canada during the COVID-19 Pandemic
}

David N. Fisman and Ashleigh R. Tuite

From the Dalla Lana School of Public Health, University of Toronto ${ }^{1}$, Toronto, Ontario, Canada

\section{Address reprint requests and correspondence to:}

David Fisman, MD MPH FRCP(C)

Room 686, 155 College Street, Toronto, Ontario, M5T 3M7

Email: david.fisman@utoronto.ca

The research was supported by a grant to DNF from the Canadians Institutes for Health Research (2019 COVID-19 rapid researching funding OV4-170360). 
medRxiv preprint doi: https://doi.org/10.1101/2021.03.23.21253873; this version posted March 26, 2021. The copyright holder for this preprint (which was not certified by peer review) is the author/funder, who has granted medRxiv a license to display the preprint in perpetuity.

It is made available under a CC-BY-NC-ND 4.0 International license .

Both Canada and the United States have advanced medical care systems, and in both countries the COVID-19 pandemic has had a major impact on population health and the economy. The similarities and differences between the two countries' healthcare systems have made crossnational comparisons an important source of insight into the strengths and weaknesses of their respective health systems (1). During the COVID-19 pandemic, both COVID-19 cases and deaths per capita have been higher in the United States than in Canada, while decline in gross domestic product has been $2.1 \%$ greater in Canada than in the U.S. (2). Greater economic losses in Canada may reflect more aggressive use of non-pharmaceutical measures such as business and school closures to reduce disease transmission. Per capita attack rates and deaths seen in the United States represent a counterfactual, which Canada might have experienced with less aggressive disease control measures.

\section{Methods and Results}

We obtained national COVID-19-attributed death estimates from Public Health Agency of Canada and the U.S. Centers for Disease Control and Prevention current as of March 14, 2021. At that time 22,290 COVID-19-attributed deaths were recorded in Canada (0.59 deaths per 1000 population), as compared to 507,227 deaths in the United States (1.56 deaths per 1000 population) (RR 2.67, 95\% CI 2.63 to 2.70$)(3,4)$. We plotted cumulative proportions of deaths by age (based on midpoints of age groups) (Figure). It can be seen that the U.S. curve for cumulative deaths by age is "pulled" to the left, demonstrating greater proportionate mortality in younger individuals in the United States. 
medRxiv preprint doi: https://doi.org/10.1101/2021.03.23.21253873; this version posted March 26, 2021. The copyright holder for this preprint (which was not certified by peer review) is the author/funder, who has granted medRxiv a license to display the preprint in perpetuity.

It is made available under a CC-BY-NC-ND 4.0 International license .

We estimated the number of excess deaths in Canada under a United States-like scenario using direct standardization. As Canadian and U.S. death data were reported using slightly different age groupings we reallocated Canadian deaths using death distributions by two-year age increments available for the province of Ontario (as of March 11, 2021). Observed deaths in Canada were divided by expected deaths based on U.S. mortality incidence to calculate standardized mortality ratios. Observed deaths were subtracted from expected deaths to calculate deaths averted (Table). Lastly, we divided averted deaths by age-specific case-fatality estimates from Ontario to estimate averted cases. We applied age-specific risks of hospital admission and intensive care admission, derived from Ontario case data, to calculate hospital and intensive care admissions averted. We estimated that the more aggressive approach to pandemic suppression employed in Canada averted approximately 6 million counted cases, 45,000 deaths, 185,000 hospital admissions and 38,000 ICU admissions that would have been seen had the country's public health response been similar in stringency to that employed in the United States. Averted hospitalizations and intensive care unit admissions were concentrated in the 50-to-74 year age band. Data used for calculations are available online at https://figshare.com/articles/dataset/Estimated Deaths Intensive Care Admissions and Hospit alizations_Averted_in_Canada_during_the_COVID-19_Pandemic/14036549.

\section{Discussion}

The Canadian response to the COVID-19 pandemic has been less effective in limiting disease and death than that seen in other large federal democracies like Australia, though there has been 
medRxiv preprint doi: https://doi.org/10.1101/2021.03.23.21253873; this version posted March 26, 2021. The copyright holder for this preprint (which was not certified by peer review) is the author/funder, who has granted medRxiv a license to display the preprint in perpetuity.

It is made available under a CC-BY-NC-ND 4.0 International license .

notable heterogeneity in the response to COVID-19 within Canada, with Atlantic provinces and Northern Territories having effectively achieved COVID-19 elimination, despite intermittent setbacks (5). However, given cultural similarities, intertwined economies, and a long, undefended border, the natural comparator for Canada's COVID-19 response is the response in the United States. Here we show that application of U.S.-derived age- and disease-specific mortality for COVID-19 to Canada would result in a counterfactual in which deaths, hospitalizations, and intensive care admissions are markedly increased. In particular, Canada's response appears to have protected middle-aged adults against severe diseases from COVID-19 far more effectively than the public health response in the United States.

There are three important limitations to our analysis: while we attribute improved outcomes in Canada to concrete public health actions, it is also possible that they reflect differences in structural, societal factors that have enhanced COVID-19 risk in the United States. Excess risk of COVID-19 and COVID-19 related death in the United States has been associated with lower income status and non-white ethnicity, but similar relationships have been observed in Canada as well $(6,7)$. A second key limitation of our analysis is our use of Ontario-specific case fatalities, and hospitalization and intensive care admission risks, to estimate outcomes averted at a national level; however, Ontario's epidemiology is likely similar to that of Canada overall, both because of similarities in demographics and health systems across the country, and also because the population of Ontario represents approximately $40 \%$ of the Canadian population, and $35 \%$ of Canada's COVID-19 case load, such that the Province's epidemiology strongly influences that of Canada as a whole. Lastly, we assume that attribution of COVID-19 deaths in Canada and the 
medRxiv preprint doi: https://doi.org/10.1101/2021.03.23.21253873; this version posted March 26, 2021. The copyright holder for this preprint (which was not certified by peer review) is the author/funder, who has granted medRxiv a license to display the preprint in perpetuity.

It is made available under a CC-BY-NC-ND 4.0 International license .

United States occurs in a comparable manner; questions around over- and under-assignment of

COVID-19 mortality have been raised in both countries (8).

Figure Legend: Cumulative Proportion of COVID-19 Attributable Death by Age, United

States and Canada, January 1, 2020 to March 12, 2021.

Ages represent the midpoints of age categories. For the oldest age categories in Canada (80 and over) and the United States ( 85 and over) we assigned an age of 90 years.

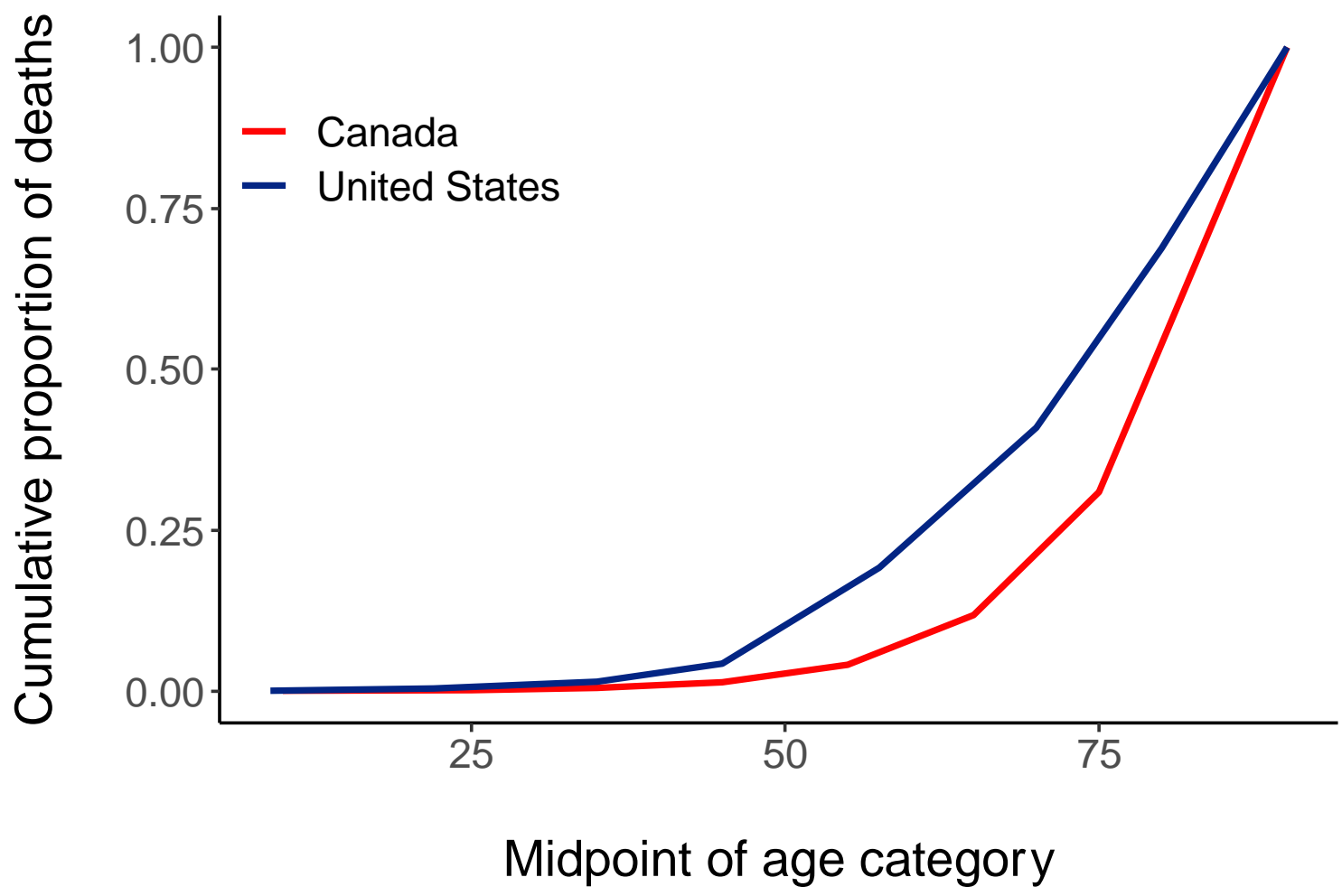




\begin{tabular}{|c|c|c|c|c|c|c|c|c|}
\hline $\begin{array}{l}\text { Age } \\
\text { Group }\end{array}$ & $\begin{array}{l}\text { Cumulative } \\
\text { Mortality per } \\
\text { 1000, US }\end{array}$ & $\begin{array}{l}\text { Expected Deaths } \\
\text { in Canadian } \\
\text { Population with } \\
\text { US Age-Specific } \\
\text { Mortality }\end{array}$ & $\begin{array}{l}\text { Observed } \\
\text { Canadian } \\
\text { Deaths }\end{array}$ & $\begin{array}{c}\text { Standardized } \\
\text { Mortality } \\
\text { Ratio }\end{array}$ & $\begin{array}{l}\text { Deaths } \\
\text { Averted }\end{array}$ & $\begin{array}{l}\text { Cases } \\
\text { Averted }\end{array}$ & $\begin{array}{c}\text { Hospitalizations } \\
\text { Averted }\end{array}$ & $\begin{array}{c}\text { ICU } \\
\text { Admissions } \\
\text { Averted }\end{array}$ \\
\hline $\begin{array}{l}0 \text { to } 17 \\
18 \text { to }\end{array}$ & 0.003 & 22 & 3 & 0.14 & 19 & 638305 & 3287 & 456 \\
\hline $\begin{array}{l}29 \\
30 \text { to }\end{array}$ & 0.03 & 206 & 38 & 0.18 & 168 & 1249970 & 7879 & 874 \\
\hline $\begin{array}{l}39 \\
40 \text { to }\end{array}$ & 0.12 & 653 & 76 & 0.12 & 577 & 1431652 & 20628 & 2856 \\
\hline $\begin{array}{l}49 \\
50 \text { to }\end{array}$ & 0.36 & 1753 & 179 & 0.10 & 1574 & 1145691 & 27739 & 6090 \\
\hline $\begin{array}{l}64 \\
65 \text { to }\end{array}$ & 1.21 & 9392 & 1329 & 0.14 & 8063 & 1038895 & 56270 & 15049 \\
\hline $\begin{array}{l}74 \\
75 \text { to }\end{array}$ & 3.51 & 13877 & 2791 & 0.20 & 11086 & 244457 & 36699 & 9146 \\
\hline $\begin{array}{l}84 \\
85 \text { and }\end{array}$ & 9.18 & 18626 & 6016 & 0.32 & 12610 & 88472 & 22913 & 3512 \\
\hline over & 26.86 & 22895 & 11858 & 0.52 & 11037 & 42117 & 10033 & 565 \\
\hline Total & & 67424 & 22290 & & 45134 & 5879559 & 185446 & 38547 \\
\hline
\end{tabular}


medRxiv preprint doi: https://doi.org/10.1101/2021.03.23.21253873; this version posted March 26, 2021. The copyright holder for this preprint (which was not certified by peer review) is the author/funder, who has granted medRxiv a license to display the preprint in perpetuity.

\author{
It is made available under a CC-BY-NC-ND 4.0 International license
If
}


medRxiv preprint doi: https://doi.org/10.1101/2021.03.23.21253873; this version posted March 26, 2021. The copyright holder for this preprint (which was not certified by peer review) is the author/funder, who has granted medRxiv a license to display the preprint in perpetuity.

It is made available under a CC-BY-NC-ND 4.0 International license .

\section{References}

1. Rouleau JL, Moye LA, Pfeffer MA, Arnold JM, Bernstein V, Cuddy TE, et al. A comparison of management patterns after acute myocardial infarction in Canada and the United States. The SAVE investigators. N Engl J Med. 1993;328(11):779-84.

2. Policy Support and Vaccines Expected to Lift Activity. Available via the Internet at https://www.imf.org/en/Publications/WEO/Issues/2021/01/26/2021-world-economic-

outlook-update. Last accessed March 16, 2021. World Economic Outlook Update.

Washington, DC: International Monetary Fund,; 2021.

3. National Center for Health Statistics 2021;Pages. Accessed at United States Centers for Disease Control and Prevention at.

4. 2021;Pages. Accessed at Public Health Agency of Canada at.

5. Riche EL. The Atlantic bubble was not only a good idea, but a blueprint for dramatic change. Available via the Internet at https://www.cbc.ca/news/canada/newfoundlandlabrador/edward-riche-atlantic-bloc-1.5874814. Last accessed March 16, 2021. CBC News Online: Canadian Broadcasting Corporation; 2021.

6. COVID-19 in Ontario - A Focus on Diversity. Available via the Internet at https://www.publichealthontario.ca/-/media/documents/ncov/epi/2020/06/covid-19-epidiversity.pdf?la=en. Last accessed March 16, 2021. Toronto, Canada: Public Health Ontario; 2021.

7. 2021;Pages. Accessed at US Centers for Disease Control and Prevention at.

8. Stokes AC, Lundberg DJ, Elo IT, Hempstead K, Bor J, Preston SH. Assessing the Impact of the Covid-19 Pandemic on US Mortality: A County-Level Analysis. medRxiv. 2021:2020.08.31.20184036. 
medRxiv preprint doi: https://doi.org/10.1101/2021.03.23.21253873; this version posted March 26, 2021. The copyright holder for this preprint (which was not certified by peer review) is the author/funder, who has granted medRxiv a license to display the preprint in perpetuity.

\author{
It is made available under a CC-BY-NC-ND 4.0 International license
If
}


medRxiv preprint doi: https://doi.org/10.1101/2021.03.23.21253873; this version posted March 26, 2021. The copyright holder for this preprint (which was not certified by peer review) is the author/funder, who has granted medRxiv a license to display the preprint in perpetuity.

\author{
It is made available under a CC-BY-NC-ND 4.0 International license
If
}

